\title{
Effects of the drying method for flowers of Cynara cardunculus var. Altilis on milk
}

\section{coagulating properties}

\author{
Carmela Tripaldi ${ }^{1}$, Giuliano Palocci ${ }^{1 *}$, Sabrina Di Giovanni ${ }^{1}$, Miriam Iacurto ${ }^{1}$, Roberto Steri ${ }^{1}$, Maria Concetta \\ Campagna $^{2}$, Cristina Di Russo ${ }^{2}$, Tiziana Zottola ${ }^{2}$
}

${ }^{1}$ Consiglio per la ricerca in agricoltura e l'analisi delleconomia agraria, Centro di ricerca Zootecnia e Acquacoltura, Monterotondo, Italy; ${ }^{2}$ Istituto Zooprofilattico Sperimentale del Lazio e Toscana, Roma, Italy

*Corresponding Author: Giuliano Palocci, Consiglio per la ricerca in agricoltura e l'analisi dell'economia agraria, Centro di ricerca Zootecnia e Acquacoltura, Monterotondo, Italy. Email: giuliano.palocci@crea.gov.it

Received: 10 March 2021; Accepted: 6 November 2021; Published: 17 November 2021

(c) 2021 Codon Publications

OPEN ACCESS (C) (1)(2)(2)

PAPER

\begin{abstract}
In the production of some traditional cheeses from vegetable rennet, raw extracts of Cynara cardunculus flowers are used as the coagulant. During the preparation of this rennet, there are many factors that can influence its coagulation activity. We studied the flowers of Cynara cardunculus var. altilis to evaluate the effects of some of these factors: ripening stage of the flower at harvest, type of drying, part of the flower subjected to drying, toasting of the pistils, and maceration time of the pistils. The results show that it is possible to improve the coagulation activity of the traditional preparation of Cynara cardunculus flowers through some practices such as the rapid drying of the flowers/pistils at a controlled temperature, the toasting treatment of the pistils carried out after the slow drying of the flowers, and the extension of the extraction time to $24 \mathrm{~h}$.
\end{abstract}

Keywords: clotting activity; Cynara cardunculus; drying process; maceration time

\section{Introduction}

The use of vegetable rennet in cheese production is limited to a few cheeses. The excessive proteolytic nature of plant coagulants can negatively affect the cheese-making process and favor a reduction in the cheese yield and the presence of some defects in flavor and texture. This may have limited the diffusion of vegetable rennet (Lo Piero et al., 2002).

An exception to this general rule is represented by the aqueous extract of Cynara cardunculus flowers, which is the most common vegetable rennet in the Mediterranean region (Barros et al., 2001).

The milk-clotting activity of this plant extract has been known for centuries and has been successfully used to produce cheeses from ovine and caprine milk (Silva et al., 2003), which are highly appreciated.
These cheeses are widespread mainly in Spain and Portugal, where in many cases only the raw extract of dried Cynara cardunculus flowers is used as a coagulant (Almeida and Simões, 2018). Furthermore, some of them (Ibores, Flor de Guia, La Serena, Torta del Casar, Azeitao, Castelo Branco, Evora, Nisa, Serpa, Serra da Estrela) have been recognized as Protected Designation of Origin (PDO), as evidence of their close link with origin area and traditional practices of cheese-making. In Italy, only a few traditional ovine cheeses are made with vegetable rennet (Caciofiore, Casoperuto).

Cheeses produced with Cynara cardunculus differ from those produced with animal rennet due to their softer texture, more intense odor, and flavor, including the bitter taste (Alavi and Momen, 2020; Barbosa et al., 1981). It has been observed that the formation of bitter taste peptides is caused by a strong proteolytic activity of thistle enzymes (Agboola et al., 2004; Alavi and Momen, 
2020). In sheep and goat cheeses produced with Cynara cardunculus extracts, a slightly bitter taste was detected (Conceição et al., 2018; Roseiro et al., 2003). Cheeses made with cow's milk tend to develop a bitter taste (Alavi and Momen, 2020; Barbosa et al., 1981).

It was found that ovine caseins are less likely than bovine caseins to form hydrophobic bitter peptides following proteolytic action (Pelissier and Manchon, 1976). According to Macedo et al. (1996), the bitter taste of the ovine cheese could be due to the formation of several peptides identifiable in the digests of isolated bovine alfa-s and beta-casein from ovine milk. The concentration of bitter peptides (those with a molecular size of 165-6500 g. mol ${ }^{-1}$ ) was the lowest in ovine cheese made from calf rennet; however, cheese made from cardoon coagulant was perceived to be less bitter by a sensory panel (Agboola et al., 2004).

Cynara cardunculus flowers produce cardosins and cyprosins, aspartic proteases that accumulate in mature flowers; in fact, the concentration of the aspartic proteases in the fresh flower is lower (Cordeiro et al., 1994).

To date, nine different aspartic proteases have been found at the protein level: six cardosins and three cyprosins (Folgado and Abranches, 2020).

Cardosins A and B were extracted from the stigmae and stylets of dried flowers of Cynara cardunculus (Silva et al., 2003). Cardosins A and B are among the aspartic proteases that are found in many varieties of plant species. Aspartic proteases are involved in protein degradation during the plant development process, protein storage mechanisms, responses to stress and pathogens, reproduction, and plant senescence (Cordeiro et al., 1994; González-Rábadea et al., 2011; Pissarra et al., 2007). Cardosin B is more proteolytic than cardosin A. In terms of activity and specificity, cardosin A is similar to chymosin as it cleaves the same peptide bond (Phe105-Met106) of $\mathrm{k}$-casein. Cardosin B is similar to pepsin; in ovine caseins, as1-casein is cleaved by cardosin B at bonds Leu156-Asp157 and Trp164-Tyr165, whereas $\beta$-casein is cleaved at peptide bonds Leu127-Thr128, Leu165-Ser166, and Leu190-Tyr191 (Macedo et al., 1993; Silva and Malcata, 1999; Silva et al., 2006; Veríssimo et al., 1995).

Cardosin A is often highlighted as being more suitable for promoting milk clotting due to its higher specificity and lower proteolytic activity than cardosin B. However, the amount of cardosin A needed for milk clotting is 10-fold higher than that of cardosin B, i.e., the specific activity of cardosin A is lower than that of cardosin B (Silva et al., 2003). According to some authors (Silva and Malcata, 1998, 1999; Silva et al., 2003), although thistle aspartic proteases cut the same peptide bond as chymosin, their proteolytic activity is more extensive. According to Conceição et al. (2018), cardosins reveal a more intense secondary proteolytic action on cheese $\alpha$ sand $\beta$-casein than other coagulants, with impact on the cheeses' biochemical and sensory properties. In addition, three cyprosins from dried flowers of Cynara cardunculus, which were isolated, purified, and characterized by Heimgartner et al. (1990), have milk-clotting activity.

Generally, vegetable rennet enzymes have been obtained by aqueous extraction of various plant organs, such as flowers, seeds, roots, and leaves. There are several different ways to prepare aqueous extracts of plant material (Sousa and Malcata, 1996).

In one method, dried whole or crushed cardoon flowers are soaked in water at room temperature for a variable time. Then, the filtrate is collected, and this crude extract is used to coagulate milk (Roseiro et al., 2003). An alternative method of extraction is grinding the dried flowers with crude kitchen salt, laying the paste on a cotton cloth, and solubilizing the enzymes by percolation with warm milk (Sousa and Malcata, 2002). The crude extract can also be further purified to obtain partially purified enzyme or pure enzyme depending upon the degree of purification (Shah et al., 2014). Milk-clotting proteases have also been produced by in vitro techniques (Shah et al., 2014).

The activity of the plant extract (Almeida and Simões, 2018) depends on numerous factors, such as the thistle flower ecotype, the part of the flower used, its stage of maturity, the drying time, the final moisture content, the $\mathrm{pH}$ of the buffer, the salt concentration of the buffer, and the homogenization time (Correia et al., 2016; Folgado and Abranches, 2020; Guiné et al., 2016; Sousa and Malcata, 1996). In particular, the different profiles of aspartic proteases found among flowers of different genotypes further increase the variability of the flower extracts and their clotting time (Folgado and Abranches, 2020). This results in cardoon extract preparations that may vary in terms of clotting and proteolytic activities, and may influence the yield and final characteristics of cheese (Sousa and Malcata, 2002).

For all these reasons, the objective of this paper was to evaluate the effects of some factors influencing the milk clotting activity of cardoon rennet to reduce its variability. Two kinds of drying methods for cardoon flowers were compared: the slow drying method adopted by a farm and an experimental fast drying method. Second, the effects of the stage of the flower on harvesting and the part of the flower subjected to drying were estimated. Finally, the effect of the extraction time of the crude extract was assessed in all samples. 


\section{Materials and Methods}

\section{Plant materials}

The flowers of Cynara cardunculus var. altilis were harvested from plants grown on a farm near Rome (Agricoltura Nuova Cooperative; Rome, Italy) in 2019. On this farm, for some years, vegetable rennet has been produced from Cynara cardunculus. This rennet, used to produce certain sheep farm cheeses, is prepared as illustrated in Figure 1. The flowers of Cynara cardunculus var. altilis, collected in the maturity stage, were dried in a cool and dry room for approximately 3 weeks (slow drying method), and then the pistils were separated from the flowers and subjected to heat treatment at $120^{\circ} \mathrm{C}$ for 15 min (toasting treatment).

Samples of flowers of Cynara cardunculus var. altilis intended for the experimental trial (Figure 2) were

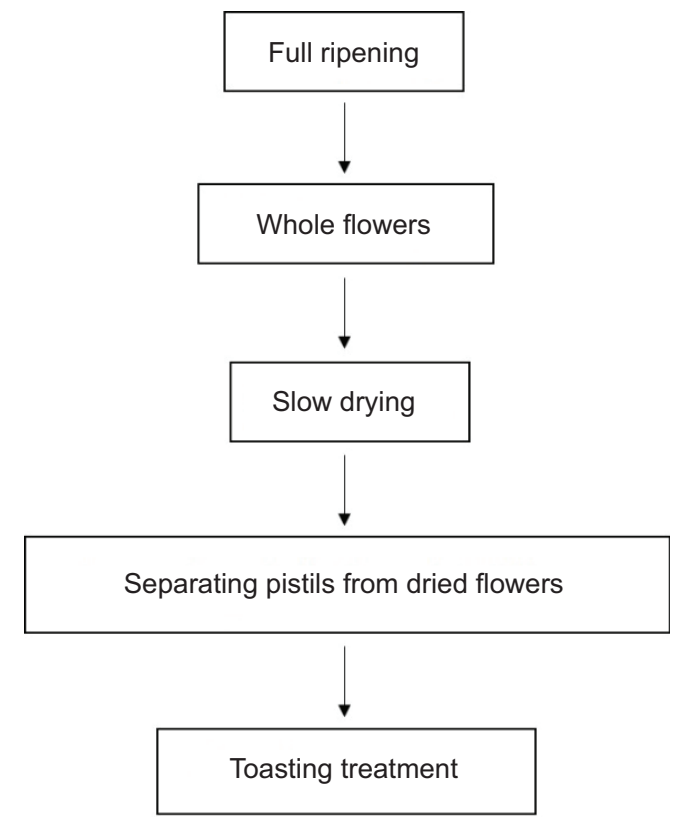

Figure 1. Method used by the farm for the preparation of rennet from Cynara cardunculus flowers.

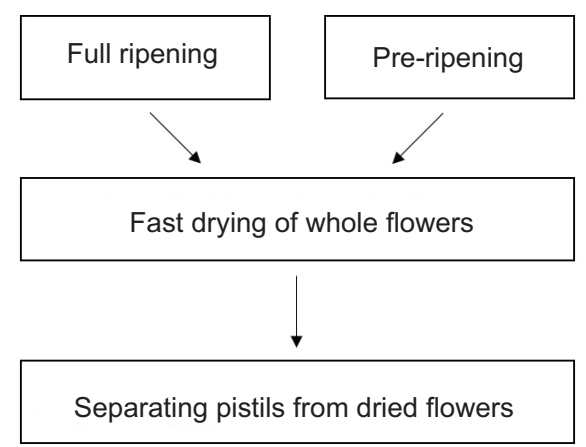

collected from the same farm both in the pre-ripening phase (not fully violet) and in the maturity stage (fully violet). All samples were subjected to fast drying of both the whole flowers and the pistils. In the first case, the pistils were separated after drying; in the second case, they were separated from the flower before drying and immediately after being collected. Fast drying was carried out at a temperature of $35^{\circ} \mathrm{C}$ with a dryer prototype, which was created by "Evoluzione Natura" company for withering, drying, dehydration, and sanitizing of plant material. The system was based on controlled forced ventilation, dehumidification, and emission of ultraviolet radiation. Water activity $\left(\mathrm{a}_{\mathrm{w}}\right)$ was measured before, during, and at the end of drying by Aqualab 4te Meter Group, Inc., USA. The experimental drying lasted about $60 \mathrm{~h}$ for the whole flowers and about $12 \mathrm{~h}$ for the pistils. During the preliminary tests, it was found that these were the times required to reach an average $\mathrm{a}_{\mathrm{w}}$ of less than 0.500 . In the end, all pistils were vacuum-packed and kept at room temperature.

\section{Rennet extraction}

To prepare the raw extracts, $2.5 \mathrm{~g}$ of pistils was soaked in $100 \mathrm{~mL}$ of tap water. The amount of pistils was the same as that used on the farm to prepare a rennet solution for traditional vegetable rennet cheese.

The pistils were kept in tap water for three maceration times: 2,15 , and $24 \mathrm{~h}$ at a temperature of $15^{\circ} \mathrm{C}$. In total, 12 raw extracts were prepared for each sample and were analyzed in duplicate for a total of 24 raw extracts.

At the end of the extraction, the extracts were filtered, and the $\mathrm{pH}$ was determined. The samples were then frozen at $-20{ }^{\circ} \mathrm{C}$ and maintained until analysis.

\section{Milk coagulation properties}

The milk clotting properties were determined by the Zannoni and Annibaldi (1981) method using the

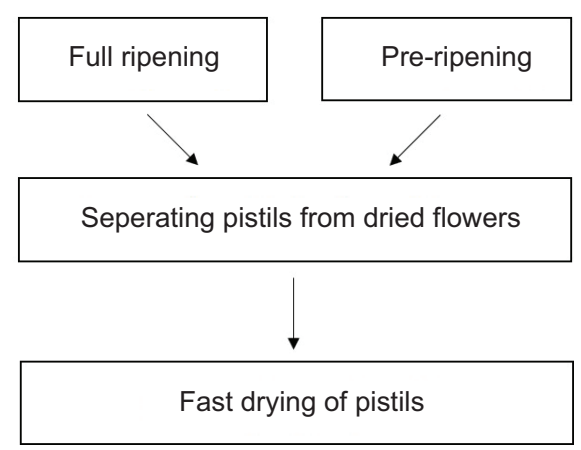

Figure 2. Experimental design for the preparation of rennet from Cynara cardunculus flowers. 
FORMAGRAPH instrument (Maspres, Firenze, Italy). Measurement is based on the movement of small pendulums immersed in linearly oscillating samples of milk. Minute forces are applied to the pendulums because of the formation of a gel in the moving milk sample. The result is the registration of the coagulation properties of the milk (McMahon and Brown, 1982). The Formagraph parameters are milk clotting time ( $r$, min), curd firming time (k20, min), and curd firmness $(\mathrm{a}, \mathrm{mm})$. The parameter $\mathrm{r}$ measures the time from the addition of the rennet to the milk up to the point where the baseline starts to increase in width (Bittante, 2011). Repeatability values within laboratories of milk clotting time were 96\% (Duranti et al., 2003). The parameter $\mathrm{k} 20$ is the interval from the start of gel development until an oscillation width of $20 \mathrm{~mm}$ is attained. The curd firmness is the width of the graph at a definite time from rennet addition (Bittante, 2011). This last parameter is measured $30 \mathrm{~min}$ after rennet addition or at twice the clotting time (a2r) (Delacroix-Buchet et al., 1994). To better estimate the curd firmness of our samples, which coagulate more slowly than those using animal rennet (Liburdi et al., 2019), we measured this parameter at 60, 75, and $90 \mathrm{~min}$ (a60, a75, a90) after adding the rennet.

The amount of pistils (50 g/100 L of milk) used to evaluate the milk clotting activity was the same as used on the farm dairy to prepare rennet solution to produce traditional vegetable rennet cheese. For each batch of samples analysis, two reference commercial coagulants were used. First: animal rennet (Hansen standard $160 \mathrm{IMCU} / \mathrm{mL}, 80 \%$ chymosin and $20 \%$ pepsin) used according to Formagraph method $(200 \mu \mathrm{l}$ of $1.6 \%$ rennet solution for $10 \mathrm{~mL}$ of milk). Second: commercial vegetable rennet (Galium, Prodor) used according to the dose indicated on the label (100 g of rennet/100 L of milk). All samples were analyzed in duplicate.

Standardized milk powder used as substrate was prepared according to ISO 23058 IDF 199: 2006. Then, 110 $\mathrm{g}$ of low-heat, low-fat, and spray-dried milk powder was added to $1 \mathrm{l}$ of $\mathrm{CaCl}_{2}$ solution $(0.5 \mathrm{~g} / \mathrm{L})$. The final $\mathrm{pH}$ of substrate was approximately 6.5. The temperature during pre-heating and analysis of the milk samples was $35^{\circ} \mathrm{C}$.

\section{Statistical analysis}

The effects of the drying method: slow method applied in farm and experimental fast method, toasting treatment applied in farm, ripening phase, part of the flower, and maceration time were analyzed using the following linear model:

$$
\mathrm{Y}=\mu+\mathrm{T}+\mathrm{e}
$$

where $\mathrm{Y}$ is the dependent variable; $\mu$ is the overall mean; $\mathrm{T}$ represents the treatments; and e is the residual error.

Statistical analysis was performed using the General Linear Model (GLM) procedure in SAS software (SAS Institute, 2011) version 9.3. The level of significance was set at $\mathrm{P}<0.05$.

The effect of $\mathrm{a}_{\mathrm{w}}$ on clotting time was analyzed. The relationship between these factors was shown by performing the Boxplot procedure (SAS software) on the mean data of groups. In fact, the $\mathrm{a}_{\mathrm{w}}$ in the experimental method was used as a threshold value (below 0.500) to fix the end of drying. In the farm, the end of drying carried out in a cool and dry room is determined by time ( 3 weeks) and the average final $\mathrm{a}_{\mathrm{w}}$ values were higher than 0.500 .

\section{Results}

Table 1 compares the effects of the two drying methods on the coagulation properties of the crude extracts. For these two samples, we started from fully ripened whole flowers being submitted to the farm method (slow drying) and then to the experimental method (fast drying). After both kind of drying, the pistils were separated from the other parts of the flower and only in the farm method the pistils were toasted. Then, to prepare the raw extracts, the toasted pistils and pistils from the fast dried flowers were used.

All the crude extracts were subjected to the three maceration times and the data shown in the tables are the results of all the maceration times.

The raw extracts prepared with farm and experimental methods reach the lowest value of curd firmness after 60 min from the addition of the rennet and the highest at 90 min. The samples produced by the experimental method showed a lower curd firming time (11.89 vs $13.88 \mathrm{~min}$ ) and higher curd firmness at 90 min after rennet addition (44.18 vs $41.27 \mathrm{~mm}$ ).

In general, better rennet capability is characterized by a brief clotting and curd firming time and an elevated curd firmness. The fast-drying rennet, named experimental method, had a better clotting ability than the rennet produced by using the slow drying method.

In Table 2, we evaluated the clotting activity of samples subjected to slow drying. Both samples were from fully mature, whole flowers. After the flowers were dried, the pistils were separated. The pistils of the sample prepared according to the farm method were toasted, while the pistils of the second sample were not toasted, in order to evaluate the specific effect of the toasting treatment. 
Table 1. Effect of drying method on milk coagulation properties.

\begin{tabular}{lcc} 
& \multicolumn{2}{c}{ Method of drying } \\
\cline { 2 - 3 } & Farm method & Experimental method \\
\hline No. of samples & 24 & 24 \\
$r(\mathrm{~min})$ & 40.19 & 42.83 \\
K20 $(\mathrm{min})$ & $13.88^{\mathrm{a}}$ & $11.89^{\mathrm{b}}$ \\
A60 (mm) & 25.37 & 26.09 \\
A75 (mm) & 35.79 & 37.41 \\
A90 (mm) & $41.27^{\mathrm{b}}$ & $44.18^{\mathrm{a}}$ \\
\hline Different letters within the same row indicate a significant difference \\
(P < 0.05).
\end{tabular}

Table 2. Effect of toasting treatment included in the farm method on milk coagulation properties.

\begin{tabular}{lll} 
& \multicolumn{2}{c}{ Toasting treatment } \\
\cline { 2 - 3 } & Yes & No \\
\hline No. of samples & 24 & 24 \\
r (min) & $40.19^{\mathrm{b}}$ & $59.53^{\mathrm{a}}$ \\
K20 (min) & 13.88 & 14.62 \\
A60 (mm) & $25.37^{\mathrm{a}}$ & $13.26^{\mathrm{b}}$ \\
A75 (mm) & $35.79^{\mathrm{a}}$ & $21.02^{\mathrm{b}}$ \\
A90 (mm) & $41.27^{\mathrm{a}}$ & $32.96^{\mathrm{b}}$ \\
\hline Different letters within the same row indicate a significant difference \\
(P< 0.05).
\end{tabular}

The characteristics evaluated were significantly different for the two types of treatments, except for the curd firming time. The coagulation time was reduced by $32 \%$ ( 40.19 vs $59.53 \mathrm{~min}$ ) in the toasted samples. The curd firmness measured after 60,75 , and 90 min was significantly higher in flowers subjected to the toasting treatment (25.37 vs $13.26 \mathrm{~mm} ; 35.79$ vs $21.02 \mathrm{~mm}$; 41.27 vs $32.96 \mathrm{~mm}$ ). Therefore, according to our results, toasting of the pistils after traditional slow drying of the flowers improves the coagulation characteristics of the thistle rennet.

Table 3 shows the effects on the crude extract characteristics of both the ripening phase and the part of flower in the samples subjected to experimental fast-drying. Significantly, lower milk coagulation times were achieved with flowers in the complete ripening phase compared to pre-ripened flowers and using directly dried pistils compared to whole dried flowers (39.96 vs $46.85 \mathrm{~min}$ and 39.77 vs $47.03 \mathrm{~min}$, respectively). The firming time values had the same tendency as the clotting time values and were lower in the complete phase and in the pistils (11.11 vs $12.24 \mathrm{~min}$ and $10.62 \mathrm{vs} 12.73 \mathrm{~min}$ ). In the pistils and in complete phase samples, the higher curd firmness values were found: 60 (30.47 vs $22.50 \mathrm{~mm}$ and $30.55 \mathrm{vs}$
Table 3. Effect of ripening phase and part of the flower submitted to experimental fast drying on milk coagulation properties.

\begin{tabular}{llllll} 
& \multicolumn{3}{c}{ Experimental fast-drying method } \\
\cline { 2 - 3 } & \multicolumn{2}{c}{ Ripening phase } & & \multicolumn{2}{c}{ Part of the flower } \\
\cline { 2 - 3 } \cline { 5 - 6 } & Pre & Full & & Whole & Pistils \\
\hline No. of samples & 48 & 48 & & 48 & 48 \\
r (min) & $46.85^{\mathrm{a}}$ & $39.96^{\mathrm{b}}$ & & $47.03^{\mathrm{a}}$ & $39.77^{\mathrm{b}}$ \\
K20 (min) & $12.24^{\mathrm{a}}$ & $11.11^{\mathrm{b}}$ & & $12.73^{\mathrm{a}}$ & $10.62^{\mathrm{b}}$ \\
A60 (mm) & $22.50^{\mathrm{b}}$ & $30.47^{\mathrm{a}}$ & & $22.42^{\mathrm{b}}$ & $30.55^{\mathrm{a}}$ \\
A75 (mm) & $33.16^{\mathrm{b}}$ & $38.79^{\mathrm{a}}$ & & $32.28^{\mathrm{b}}$ & $39.66^{\mathrm{a}}$ \\
A90 (mm) & $41.31^{\mathrm{b}}$ & $45.15^{\mathrm{a}}$ & & $40.33^{\mathrm{b}}$ & $46.14^{\mathrm{a}}$ \\
\hline Different letters within the same row indicate a significant difference \\
(P $<0.05)$.
\end{tabular}

Table 4. Effect of maceration time of the crude extracts on milk coagulation properties.

\begin{tabular}{llll} 
& \multicolumn{3}{c}{ Hours } \\
\cline { 2 - 4 } & $\mathbf{2 h}$ & $\mathbf{1 5 h}$ & $\mathbf{2 4 ~ h}$ \\
\hline No. of samples & 64 & 64 & 64 \\
pH & $5.97^{\mathrm{a}}$ & $5.76^{\mathrm{ab}}$ & $5.66^{\mathrm{b}}$ \\
$\mathrm{r}(\mathrm{min})$ & $48.71^{\mathrm{a}}$ & $44.82^{\mathrm{b}}$ & $40.67^{\mathrm{c}}$ \\
K20 & $13.62^{\mathrm{a}}$ & $12.11^{\mathrm{b}}$ & $11.03^{\mathrm{c}}$ \\
A60 (mm) & $22.10^{\mathrm{b}}$ & $25.05^{\mathrm{ab}}$ & $28.17^{\mathrm{a}}$ \\
A75 (mm) & $29.27^{\mathrm{c}}$ & $34.13^{\mathrm{b}}$ & $39.11^{\mathrm{a}}$ \\
A90 (mm) & $37.20^{\mathrm{c}}$ & $41.80^{\mathrm{b}}$ & $45.80^{\mathrm{a}}$ \\
\hline
\end{tabular}

Different letters within the same row indicate a significant difference $(P<0.05)$.

$22.42 \mathrm{~mm}$ ), 75 (38.79 vs $33.16 \mathrm{~mm}$ and $39.66 \mathrm{vs} 32.28$ $\mathrm{mm}$ ), and $90 \mathrm{~min}$ after rennet addition (45.15 vs 41.31 $\mathrm{mm}$ and $46.14 \mathrm{vs} 40.33 \mathrm{~mm}$ ).

The effects of the maceration times of the raw extracts at 2,15 , and $24 \mathrm{~h}$ are shown in Table 4 . The evaluation of the maceration time was carried out on all the samples and included all the treatments (pre-ripening and ripening phase, whole flowers and pistils, farm and experimental drying, toasting or not). For all parameters, the results obtained at the three maceration times were significantly different. The best coagulation aptitude was obtained after $24 \mathrm{~h}$ of maceration: clotting and curd firming times of crude extracts were lower, and curd firmness at 60, 75 , and 90 min was higher. $\mathrm{pH}$ values decreased with increasing extraction time.

The correlation coefficients among the Formagraph parameters were analyzed for all samples. We found that all correlation coefficients were significant $(\mathrm{P}<0.0001)$ : +0.70 between $\mathrm{r}$ and $\mathrm{k} 20 ;-0.73,-0.86,-0.90$ between 
k20 and a60, a75, a90, respectively; $-0.94,-0.95,-0.88$ between $\mathrm{r}$ and a60, a75, a90, respectively. Formagraph parameters from raw extracts were highly correlated, i.e., clotting time and curd firming time were positively correlated, and both were negatively correlated with curd firmness. In raw extracts and standard rennet, when the coagulation time is longer, the time necessary to firm the curd is extended. The greater the curd firmness, the more the milk coagulates in a short time. The coagulation activity is good when the coagulation time is shorter, and the curd consistency is greater.

Similarly, the correlation coefficients $(\mathrm{P}<0.0001)$ found for cow milk coagulated with animal rennet (Mariani et al., 1997) were +0.58 between $\mathrm{r}$ and $\mathrm{k} 20$; -0.80 between $\mathrm{k} 20$ and $\mathrm{a} 30$; and -0.89 between $\mathrm{r}$ and $\mathrm{a} 30$.

All samples during Formagraph analysis were compared with the reference coagulants, i.e., animal and commercial vegetable rennet whose average data were, respectively: r 14.52 and $11.38 \mathrm{~min}$; k20 2.79 and $2.23 \mathrm{~min}$; A30 44.70 and $50.30 \mathrm{~mm}$; A2r 44.52 and 44.20.

Figure 3 shows the box plot of the distribution of clotting time according to $a_{w}$ classes. We observed that the two samples with higher $\mathrm{a}_{\mathrm{w}}$ had higher coagulation time.
These samples came from whole flowers collected at a pre-ripening stage and quickly dried (PR-WF-FD) $\left(\mathrm{a}_{\mathrm{w}}\right.$ $=0.623$ ) and from whole flowers slowly dried and not toasted (FR-WF-SD-NT) (0.557). The other samples had lower $\mathrm{a}_{\mathrm{w}}$ and faster clotting times. These included FR-WF-SD-T slowly dried and toasted samples (0.457); PR-P-FD pistils quickly dried from premature (0.401) and FR-P-FD mature flowers (0.324); and FR-WF-FD whole flowers dried quickly and collected when fully ripe (0.323).

\section{Discussion}

According to the classification of the milk coagulation properties with animal rennet by the method of Zannoni and Annibaldi (1981), good-quality cow milk has a clotting time between 11:30 and 18:00 min.

The results obtained from the raw extracts showed very long milk coagulation times: from 40.19 min with the farm method to 42.83 min with the experimental method, compared to 14.52 min with reference animal rennet. Regarding curd firmness, 90 min after adding the rennet (A90), it ranged from $41.27 \mathrm{~mm}$ (farm method) to 44.18 $\mathrm{mm}$ (experimental method). These values are comparable

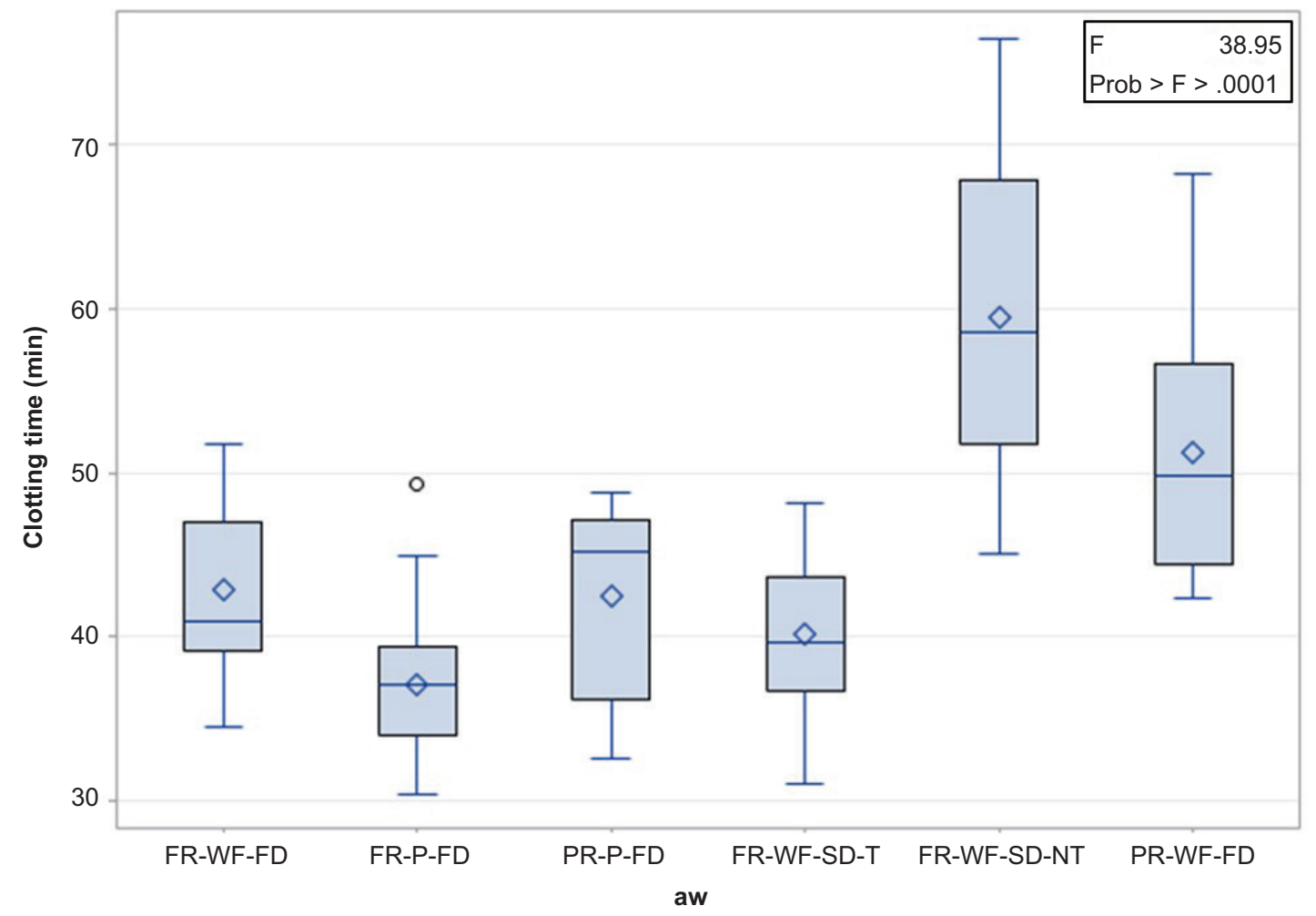

Figure 3. Box Plot of distribution of clotting time according to $a_{w}$ classes. FR: full ripening; WF: whole flower; FD: fast drying (experimental method); P: pistils; PR: pre-ripened; SD: slow dried; T: toasted; NT: not toasted. 
with those obtained $30 \mathrm{~min}$ after the addition of the animal rennet $(44.70 \mathrm{~mm})$. These results suggest that, by coagulating cow's milk with raw extracts prepared both with the farm and experimental methods, it is possible to obtain curd firmness similar to that obtained with animal rennet by extending the total coagulation time by $1 \mathrm{~h}$.

Similar results were found by Liburdi et al. (2019) for samples of cow's milk coagulated with Cynara cardunculus and analyzed by Formagraph: coagulation time of $42.30 \mathrm{~min}$ and firmness of the curd after $60 \mathrm{~min}$ equal to $29.45 \mathrm{~mm}$.

In cheese from animal rennet, the parameters of milk clotting activity are related to cheese yield; it was demonstrated that a faster coagulation time and firmer curd were positively correlated with cheese yield (Aleandri et al., 1989; Johnson et al., 2001; Ng-Kwai-Hang et al., 1989; Okigbo et al., 1985; Pretto et al., 2012). Moreover, the reduction in coagulation time is an undoubted advantage, as it contributes to decreasing the duration of the process.

In a recent paper, Ben Amira et al. (2017) studied the technological properties of milk gels produced by chymosin and wild cardoon rennet (C. cardunculus var. sylvestris). Higher curd firmness, similar to chymosin values, was obtained following the optimization of extraction conditions of wild cardoon rennet. It would be interesting to evaluate the effects of different coagulating activities of the raw extracts of Cynara cardunculus on the yield and characteristics of the cheese. Regardless, the effects of any changes in the preparation of vegetable rennet on the characteristics of traditional cheese should not be overlooked.

The results of the correlation between the $\mathrm{a}_{\mathrm{w}}$ of the flowers/pistils and the clotting time suggest that the $\mathrm{a}_{\mathrm{w}}$ should be less than 0.45 so that the clotting time is less than 45 min. In traditional practice, which always starts from fully ripe flowers, the addition of toasting of the pistils, which follows the slow drying of the flowers, is very effective in reducing the $a_{w}$ and the clotting time. If fast drying is performed, the factors that favor the reduction of $a_{w}$ are the collection of flowers at the fully ripe stage and the direct drying of the pistils. The best result, in terms of clotting time, was obtained from the pistils obtained from the ripe flowers and dried directly. However, separation of the pistils from the flowers before drying is time-consuming, which means higher costs to produce vegetable rennet.

In the flowers, the quantity of enzyme increased during development and was mainly present in the purple parts of styles and corollas. The maximum activity of enzymes observed in mature flowers may indicate involvement in the senescence process (Cordeiro et al., 1994). Clotting times decreased as flower development progressed due to increased enzymatic activities in the extracts (Cordeiro et al., 1994).

According to Martins et al. (1996), the drying time of thistle flowers subjected to the traditional method gave the following results. The $a_{w}$ decreased from fresh $\left(a_{w}\right.$ $0.866)$ to medially dried ( 1 day): 0.674 and dried (30 days): 0.592. Better clotting activity was observed in medially dried flowers on a wet and dry matter basis. In contrast, Ordiales et al. (2012) investigated the milk-clotting activity of Cynara cardunculus at three ripening stages: opening of flower, flower fully open, and flower beginning to dry out. Milk clotting activities of aqueous extracts after maceration for 1 and $24 \mathrm{~h}$ did not vary significantly according to the ripening stages.

On the other hand, Cynara cardunculus, including its variety altilis (Ramos et al., 2014), is a source of phenolic compounds. The content of phenolic compounds was highest in the early stages of maturation and decreased as the maturity stage progressed (Mandim et al., 2020). Phenolic compounds could have a role in the clotting activity of flowers. Protein-polyphenol interactions were reported to modify the functional properties of foods (Yildirim-Elikoglu and Erdem, 2018). Phenolic compounds are easily oxidized to form pigments. These pigments attach to proteins, including native enzymes, leading to inactivation of these enzymes (Barros et al., 2001). The interactions between casein micelles and polyphenols decrease the enzymatic gelation properties at both the first and second stages of the renneting process (Haratifar and Corredig, 2014).

Considering that the crude extract is often contaminated by other floral compounds, such as phenolic compounds (Conceição et al., 2018), it can be assumed that the best performance of mature flowers could be due to both the greater content of proteases and to the lower content of polyphenols.

Among the different treatments used to prepare vegetable rennet from Cynara cardunculus flowers, the toasting treatment was very effective at improving clotting activity. Some hypotheses can be made to explain this positive effect. In a study (Wang et al., 2008) on bitter gourd, it was shown that aspartic protease was activated by heating treatment. Only few APs of the plant have been functionally characterized. For most APs of the plant, a definitive role was not assigned (Wang et al., 2008).

The results obtained with the different maceration times indicate that the longer the extraction time, the greater the coagulating activity of the raw extract. The same trend was observed in Cynara cardunculus flowers by 
Ordiales et al. (2012), who reported better results after $24 \mathrm{~h}$ than after $1 \mathrm{~h}$ of maceration. Ben Amira et al. (2017), studying a model based on four variables to optimize the extraction conditions of Cynara cardunculus, found that the best extraction time was 50 min compared to 145 and $240 \mathrm{~min}$

\section{Conclusions}

The results indicate that it is possible to improve the coagulating activity of the crude extract of Cynara cardunculus by modifying the rennet preparation process. The most effective innovations compared to the traditional process were the toasting treatment following the slow drying of the flowers and the fast drying of the flowers/pistils at a controlled temperature. Extending the extraction time can further improve clotting activity. During the production of typical cheeses, it is necessary to evaluate whether innovations in the preparation of vegetal rennet can lead to changes in the characteristics of the cheese.

\section{Acknowledgements}

We would like to thank Agricoltura Nuova Cooperative, Rome, Italy, for their kind cooperation and for providing the samples of plant materials.

\section{Funding}

This research was funded by the Italian Ministry of Health within the project "Formaggi di bufala prodotti con caglio vegetale ed arricchiti con antiossidanti naturali-Buffalo cheeses produced with vegetable rennet and enriched with natural antioxidants."

\section{References}

Agboola, S., Chen, S. and Zhao, J., 2004. Formation of bitter peptides during ripening of ovine milk cheese made with different coagulants. Lait 84: 567-578. https://doi.org/10.1051/lait:2004032

Alavi, F. and Momen, S., 2020. Aspartic proteases from thistle flowers: traditional coagulants used in the modern cheese industry. International Dairy Journal 107: 104709. https://doi. org/10.1016/j.idairyj.2020.104709

Aleandri, R., Schneider, J.C. and Buttazzoni, L., 1989. Evaluation of milk for Cheese production based on milk characteristics and formagraph measures. Journal Dairy Science 72: 1967-1975. https://doi.org/10.3168/jds.S0022-0302(89)79319-X

Almeida, C.M. and Simões, I., 2018. Cardoon-based rennets for cheese production. Applied Microbiology Biotechnology 102: 4675-4686. https://doi.org/10.1007/s00253-018-9032-3
Barbosa, M., Corradini, C. and Battistotti, B., 1981. Cheese-making experiments carried out on some Italian cheeses with vegetable rennet from cardo (Cynara cardunculus L.). Scienza Tecnica Lattiero Casearia 32: 203-221.

Barros, R.M., Ferreira, C.A., Silva, S.V. and Malcata, F.X., 2001. Quantitative studies on the enzymatic hydrolysis of milk proteins brought about by cardosins precipitated by ammonium sulfate. Enzyme Microbiology Technology 29: 541-547. https:// doi.org/10.1016/S0141-0229(01)00431-8

Ben Amira, A., Makhlouf, I., Flaviu Petrut, R., Francis, F., Bauwens, J., Attia, H., Besbes, S. and Blecker, C., 2017. Effect of extraction $\mathrm{pH}$ on techno-functional properties of crude extracts from wild cardoon (Cynara cardunculus L.) flowers. Food Chemistry 225: 258-266. https://doi.org/10.1016/j.foodchem.2017.01.040

Bittante, G., 2011. Modeling rennet coagulation time and curd firmness of milk. Journal Dairy Science 94: 5821-5832. https://doi. org/10.3168/jds.2011-4514

Conceição, C., Martins, P., Alvarenga, N., Dias, J., Lamy, E., Garrido, L., Gomes, S., Freiras, S., Belo, A., Brás, T., Paulino, A. and Duarte, M.F., 2018. Cynara cardunculus: use in cheesemaking and pharmaceutical applications. In: Koca, N. (ed.) Technological approaches for novel applications in dairy processing. Intech Open, Vol. 1, pp. 73-107.

Cordeiro, M.C., Salome, M.P. and Brodelius, P.E., 1994. Tissuespecific expression of multiple forms of cyprosin (aspartic proteinase) in flowers of Cynara cardunculus. Physiology Plant 92: 645-653. https://doi.org/10.1111/j.1399-3054.1994.tb03035.x

Correia, P., Vítor, A., Tenreiro, M., Correia, A.C., Madanelo, J. and Guiné, R.P.F., 2016. Effect of different thistle flower ecotypes as milk-clotting in Serra da Estrela cheese. Nutrition Food Science 46: 458-475. https://doi.org/10.1108/NFS-12-2015-0157

Delacroix-Buchet, A., Barillet, F. and Lagriffoul, G., 1994. Caractérisation de l'aptitude fromagère des laits de brebis Lacaune à l'aide d'un Formagraph. Lait 74: 173-186. https://doi. org/10.1051/lait:1994315

Duranti, E., Bolla, P., Caroli, A., Chiofalo, L., Di Stasio, L., Fortina, R., Martini, M., Piccolo, V. and Zullo, A., 2003. Problems concerning ovine milk clotting aptitude. Italian Journal Animal Science 2: 89-95. https://doi.org/10.4081/ijas.2003.89

Folgado, A. and Abranches, R., 2020. Plant aspartic proteases for industrial applications: thistle get better. Plants (Basel) 9: 147156. https://doi.org/10.3390/plants9020147

González-Rábadea, N., Badillo-Corona, J.A., Aranda-Barradas, J.S. and Oliver-Salvador, M.d.C., 2011. Production of plant proteases in vivo and in vitro - a review. Biotechnology Advances 29: 983996. https://doi.org/10.1016/j.biotechadv.2011.08.017

Guiné, R.P.F., Tenreiro, M.I.C. and Correia, A.C., 2016. Analysis of factors influencing the physical, chemical and sensorial properties of Serra da Estrela cheeses. Food Measure 10: 643-657. https://doi.org/10.1007/s11694-016-9348-6

Haratifar, S. and Corredig, M., 2014. Interactions between tea catechins and casein micelles and their impact on renneting functionality. Food Chemistry 143: 27-32. https://doi.org/10.1016/j. foodchem.2013.07.092

Heimgartner, U., Pietrzak, M., Geertsen, R., Brodelius, P., da Silva Figueiredo, A.C. and Pais, M.S.S., 1990. Purification and 
partial characterization of milk clotting proteases from flowers of Cynara cardunculus. Phytochemistry 29(5): 140-141. https:// doi.org/10.1016/0031-9422(90)80090-4

ISO 23058 - IDF 199: 2006. Milk and milk products - ovine and caprine rennets - determination of total milk - clotting activity.

Johnson, M.E., Chen, C.M. and Jaeggi, J.J., 2001. Effect of rennet coagulation time on composition, yield, and quality of reducedfat cheddar cheese. Journal of Dairy Science 84(5): 1027-1033. https://doi.org/10.3168/jds.S0022-0302(01)74562-6

Liburdi, K., Boselli, C., Giangolini, G., Amatiste, S. and Esti, M., 2019. An evaluation of the clotting properties of three plant rennets in the milks of different animal species. Foods 8: 600-612. https://doi.org/10.3390/foods8120600

Lo Piero, A.R., Puglisi, I. and Petrone, G., 2002. Characterization of "lettucine," a serine-like protease from Lactuca sativa leaves, as a novel enzyme for milk clotting. Journal Agricultural Food Chemitry 50: 2439-2443. https://doi.org/10.1021/jf011269k

Macedo, I.Q., Faro, C.J. and Pires, E.M., 1993. Specificity and kinetics of the milk-clotting enzyme from cardoon (Cynara cardunculus L.) towards bovine $\mathrm{k}$-casein. Journal Agricoltural Food Chemistry 41: 1537-1540. https://doi.org/10.1021/jf00034a001

Macedo, I.Q., Faro, C.J. and Pires, E.M., 1996. Caseinolytic specificity of cardosin, an aspartic protease from cardoon Cynara cardunculus L.: action on bovine alfa-s1 and beta-casein and comparison with chymosin. Journal Agricultural Food Chemistry 44: 42-47. https://doi.org/10.1021/jf9406929

Mandim, F., Spyridon, A.P., Kyriakos, D.G., Dias, M.I., Fernandes, Â., Pinela, J., Kostic, M., Soković, M., Barros, L., Santos-Buelga, C. and Ferreira, I.C.F.R., 2020. Seasonal variation of bioactive properties and phenolic composition of Cynara cardunculus var. altilis. Food Research International 134: 109281. https://doi. org/10.1016/j.foodchem.2020.127744.

Mariani, P., Summer, A., Zanzucchi, G. and Fieni, S., 1997. Relazione tra la consistenza del coagulo - valutata con differenti criteri mediante Formagraph - e il contenuto di caseina del latte. Annali Facoltà Medicina Veterinaria, Università Parma 17: 195-204.

Martins, A.P.L., De Vasconcelos, M.P. and De Sousas, R.B., 1996. Thistle (Cynara cardunculus L) flower as a coagulant agent for cheesemaking. Short characterization. Lait 76: 473-477. https:// doi.org/10.1051/lait:1996536

McMahon, D.J. and Brown, R.J., 1982. Evaluation of formagraph for comparing rennet solutions. Journal Dairy Science 65: 16391642. https://doi.org/10.3168/jds.S0022-0302(82)82390-4

Ng-Kwai-Hang, K.F., Politis, I., Cue, R.I. and Marziali, A.S., 1989. Correlations between coagulation properties of milk and cheese yielding capacity and cheese composition. Canadian Institute Food Science Technology Journal 22: 291-294. https://doi. org/10.1016/S0315-54.63(89)70397-7

Okigbo, L.M., Richardson, G.H., Brown, R.J. and Ernstrom, C.A., 1985. Coagulation properties of abnormal and normal milk for individual cow quarters. Journal Dairy Science 68: 1893-1895. https://doi.org/10.3168/jds.S0022-0302(85)81046-8

Ordiales, E., Martín, A., Benito, M.J., Hernández, A., RuizMoyano, S. and Córdoba, M.G., 2012. Technological characterisation by free zone capillary electrophoresis (FCZE) of the vegetable rennet (Cynara cardunculus) used in "Torta del Casar" cheese-making. Food Chemistry 133: 227-235. https://doi. org/10.1016/j.foodchem.2012.01.012

Pelissier, J.P. and Manchon, P., 1976. Comparative study of the bitter taste of enzymic hydrolysates from cow, ewe and goat caseins. Journal Food Science 41: 231-233. https://doi. org/10.1111/j.1365-2621.1976.tb00590.x

Pissarra, J., Pereira, C., Soares da Costa, D., Figueiredo, R., Duarte, P., Teixeira, J. and Pereira, S., 2007. From flower to seed germination in Cynara cardunculus: a role for aspartic proteinases. International Journal Plant Development Biology 1: 274281. Available at: https://hdl.handle.net/10216/82523

Pretto, D., De Marchi, M., Penasa, M. and Cassandro, M., 2012. Effect of milk composition and coagulation traits on Grana Padano cheese yield under field conditions. Journal of Dairy Research 80: 1-5. https://doi.org/10.1017/S0022029912000453

Ramos, P.A.B., Santos, S.A.O., Guerra, Â.R., Guerreiro, O., Freire, C.S.R., Rocha, S.M., Duarte, M.F. and Silvestre, A.J.D., 2014. Phenolic composition and antioxidant activity of different morphological parts of Cynara cardunculus L. var. altilis (DC). Industrial Crops Products 61: 460-471. https://doi. org/10.1016/j.indcrop.2014.07.042

Roseiro, L.B., Barbosa, M., Ames, J.M. and Wilbey, R.A., 2003. Cheesemaking with vegetable coagulants - the use of Cynara L. for the production of ovine milk cheeses. International Journal Dairy Technology 56: 76-85. https://doi. org/10.1046/j.1471-0307.2003.00080.x

Shah, M.A., Mir, S.A. and Paray, M.A., 2014. Plant proteases as milk-clotting enzymes in cheesemaking: a review. Dairy Science and Technology 94: 5-16. https://doi.org/10.1007/ s13594-013-0144-3

Silva, S.V., Allmere, T., Malcata, F.X. and Andrén, A., 2003. Comparative studies on the gelling properties of cardosins extracted from Cynara cardunculus and chymosin on cow's skim milk. International Dairy Journal 13: 559-564. https://doi. org/10.1016/S0958-6946(03)00075-X

Silva, S.V. and Malcata, F.X., 1998. Proteolysis of ovine caseins by cardosin A, an aspartic acid proteinase from Cynara cardunculus L. Lait 78: 513-519. https://doi.org/10.1051/lait:1998548

Silva, S.V. and Malcata, F.X., 1999. On the activity and specificity of cardosin B, a plant proteinase, on ovine caseins. Food Chemistry 67: 373-378. https://doi.org/10.1016/S0308-8146(99)00126-0

Silva, S.V., Pihlanto, A. and Malcata, F.X., 2006. Bioactive peptides in ovine and caprine cheese like systems prepared with proteases from Cynara cardunculus. Dairy Science 89: 3336-3344. https://doi.org/10.3168/jds.S0022-0302(06)72370-0

Sousa, M.J. and Malcata, F.X., 1996. Effects of processing conditions on the caseinolytic activity of crude extracts of Cynara cardunculus L. Food Science Technology International 2: 255-263. https://doi.org/10.1177\%2F108201329600200408

Sousa, M.J. and Malcata, F.X., 2002. Advances in the role of a plant coagulant (Cynara cardunculus) in vitro and during ripening of cheeses from several milk species. Lait 82: 151-170. https://doi. org/10.1051/lait:2002001

Veríssimo, P., Esteves, C., Faro, C. and Pires, E., 1995. The vegetable rennet of Cynara cardunculus L. contains two proteinases with 
chymosin and pepsin-like specificities. Biotechnology Letters 17: 621-626. https://doi.org/10.1007/BF00129389

Wang, L., Wang, M., Li, Q., Cai, T. and Jiang, W., 2008. Partial properties of an aspartic protease in bitter gourd (Momordica charantia L.) fruit and its activation by heating. Food Chemistry 108: 496-502. https://doi.org/10.1016/j.foodchem.2007.10.085

Yildirim-Elikoglu, S. and Erdem, Y.K., 2018. Interactions between milk proteins and polyphenols: binding mechanisms, related changes, and the future trends in the dairy industry. Food Reviews International 34: 665-697. https://doi.org/10.1080/875 59129.2017.1377225

Zannoni, M. and Annibaldi, S., 1981. Standardization of the renneting ability of milk by formagraph - I. Scienza Tecnica Lattiero Casearia 32: 79-94. 